\title{
Ambiguity of Television's Religious Broadcasting Programs: Between Education or Reality
}

\author{
Bono Setyo $^{1 *}$, Lelita Azaria ${ }^{2}$, Khoiro Ummatin ${ }^{3}$ \\ ${ }^{1,3}$ UIN Sunan Kalijaga, Jl. Marsda Adhisucipto, Sleman, Yogyakarta, Indonesia \\ ${ }^{2}$ Universitas Gadjah Mada, Bulaksumur, Yogyakarta, Indonesia \\ *Corresponding author, e-mail: bono.setyo@uin-suka.ac.id
}

\begin{abstract}
A peaceful life is one of the essential hopes of every individual. This hope was captured as an opportunity by the media industry to produce religious broadcast television programs. Religious programs get viewers' attention shown through high ratings that can attract advertisers. The problem that occurs is related to broadcast quality. The function of the media is as a means of education and information. This study uses a qualitative approach with a descriptive study to describe the results of the study. The results showed an imbalance of religious broadcast content, which tended to Islamic content. Some programs even display horror and mystical which is not in accordance with the religious content. Almost all religious program broadcasters are stuck on the strength of the program name and the figure of the messenger. This imbalance shows the ambiguity of the function of mass media as an educational medium.
\end{abstract}

Keywords: Broadcast Program Ambiguity; Education; Mass Media; Commercialization

\begin{abstract}
Abstrak
Kehidupan yang damai dan tenang menjadi salah satu harapan esensial setiap individu. Harapan ini kemudian yang ditangkap sebagai peluang oleh industri media untuk memproduksi program siaran religi di televisi. Program ini nampak mendapat tempat dimata khalayak terbukti dengan beberapa program memiliki rating tinggi dan mampu menarik pengiklan. Permasalahan yang terjadi adalah berkaitan dengan kualitas siaran. Fungsi media adalah sebagai sarana pendidikan, dan informasi. Ambiguitas antara fungsi edukasi khususnya dalam meningkatkan toleransi keberagaman dan kepercayaan dengan fungsi komersialisasi melalui siaran religi nampak terlihat. Penelitian ini menggunakan pendekatan kualitatif dengan study deskriptif untuk memaparkan hasil penelitian. Hasil dari penelitian ini menunjukkan terdapat ketidak berimbangan konten siaran religi yang cenderung pada konten islamis, beberapa program masih memperlihatkan konten-konten tren berbau horor dan mistis. Hampir seluruh tayangan program religi, juga masih terjebak pada kekuatan nama program dan figur penyampai pesan. Ketidak berimbangan ini menunjukan ambiguitas fungsi dari media massa sebagai salah satu media edukasi.
\end{abstract}

Kata Kunci: Ambiguitas Program Siaran; Edukasi; Media Massa; Komersialisasi 


\section{Introduction}

The existence of information media that continues to develop over time makes it easier for information owners to share and produce information quickly, simultaneously, and instantly. The development of this information media is unavoidable and will continue with the times. This condition indirectly requires humans to make information a major need in their lives. Mass media is one of the media that provides information to the public. The mass media are part of a special and unique process in which communities are formed and inhabited by humans because, basically, in communicating, humans use various media to send messages. Mass media has institutionalized characteristics, and messages are massive and fast (Sorlin, 2013). Mass media is an unavoidable part of the communication process in human life. This makes the mass media have a strategic position as a medium in communication.

The presence of new media in the industrial era 4.0 does not necessarily shift the position of mass media as information media in Indonesia (Haqqu \& Azwar Ersyad, 2020). Mass media has characteristics not owned by new media, namely institutionalized. The mass media produces messages through various stages and regulations so that the message conveyed to the public can be accounted for its credibility (Liu et al., 2020). In addition, mass media has the advantage of being able to reach areas or areas that have not been touched by the internet. In other words, the mass media can reach a wider audience. Along with the development of information and communication technology, the mass media is still one of the effective communication media, one of which is used in the context of community development.

One of the mass media that is currently still in great demand and favored by the public is television (Abdullah \& Puspitasari, 2018). Several regions in Indonesia also still position television as the main source of information, and television has a central position in society (Andung et al., 2018). The influence of television through its audiovisual media can be easily accepted by audiences from various circles and regions. According to the research conducted by Nielsen Television Audience Measurement (TAM) in 2020, there was an increase in the number of television viewers seen through ratings which increased by $1.8 \%$, from $12 \%$ to $13.8 \%$. This is equivalent to an additional 1 million TV viewers. In addition, the duration of watching TV has also increased by 40 minutes(Tupani, 2020). This increase is due to the current COVID-19 pandemic that is happening. Kominfo, through the Digital Literacy Status Survey 2020 in 34 provinces in Indonesia, shows that television media is the most trusted information media in relation to seeking the truth of information (Ministry of Communication and Information, 2020).

Public trust in television is also supported by research conducted by the Indonesian Broadcasting Commission. Based on the data presented by the IDN Research Institute, television consumption for ages 21-36 is still relatively high. Through these data, $89 \%$ of the public trust the information presented on television more than on the internet (RG, 2020). Kominfo research in 34 provinces in Indonesia also shows that $49.5 \%$ of respondents are more confident in accessing television than social media of $20.3 \%$. This is because the information provided through television has gone through the stages of layered verification, check and re-check, and can be accounted for (Döveling et al., 2010; Irfan, 2020; Liu et al., 2020). This shows that the public is aware of the importance of obtaining credible information. This condition also shows that there is hope from the Indonesian people to get information that matches their expectations through television. 
The mass media, in this case, has a strategic role in relation to community development, namely in providing information and educating (Hendra, 2019; Servaes, 2020). The mass media, as an independent institution, is one of the pillars of community development (Baruah \& Hazarika, 2020; Wilkins, KG, Tufte, T., and Obregon, 2014). The importance of the role of mass media in the communication process is efficient in reaching the audience. Ideally, television as a mass media functions as a medium of information, education, and influence(Romli, 2017; Xu, 2015). In addition, according to McQuail, media operates in the public sphere based on the interests of users, where the messages in it are professional and free of interest values (Susanto, 2017). In Indonesia, broadcasting media regulations are regulated by Law no. 32 of 2002 Article 4 Paragraph 1 also states that broadcasting as a mass communication activity functions as a medium of information, education, healthy entertainment, control, and social congeal.

Television has a strategic role in providing education, constructive information, and preventing conflict (Hendra, 2019; Nicolaou, 2021; Santosa, 2017; Wilkins, KG, Tufte, T., and Obregon, 2014). Various broadcast programs are served to meet the needs of the audience, ranging from news programs, infotainment, entertainment, animation, variety shows to religion. The religious broadcast program is one of the broadcast programs in great demand by the audience because most people in Indonesia are still traditional. Traditional people trust and idolize figures according to their group (Shah, 2011). Each television station has a religious broadcast program so that the audience is served with a variety of religious content.

The diversity of religious broadcast programs presented by television stations seems to no longer only provide information and education functions but also entertainment and commercial. Alansori and Zahidi (2019), the television show like the current trend of Da'wahtainment programs in Indonesia is a promising commodity. Television broadcast industry products in the form of religious broadcasts are used as commodities and part of popular culture products by looking at the needs and interests of the market (Alansori \& Zahidi, 2019; Alfian, 2014). Pradesa and Ardilla (2020) see the commodification in Islamic religious shows that Indah is able to be maintained within ten years. This commodification is also shown through a religious program that is dominated by commercial interests (Thadi, 2020). The appearance of religion in television media tends to be colored by the principles of commercialization and capitalism (Wibowo, 2020).

This interest then demands television stations to meet the demands of the parties involved, such as the background and identity of the television station institution that affects the broadcast content. The identity of Muhammadiyah attached to the private station agency AdiTV greatly affects the content and quality standards of its broadcasts to survive in the long term(Ulfah, 2014). The Islamic religious program that is Beautiful maintains the name of the program, preachers, and event settings to be able to maintain the existence of broadcast programs (Pradesa \& Ardilla, 2020). This condition declines the television's ideal function standard as a medium of information and education due to the demands and needs for commercialization from the television station. Journalists do not have authority and idealism in presenting information (Aprinta, 2016).

On the one hand, television broadcast programs are expected to fulfill the basic function of the mass media, especially the educational function. On the other hand, recently, there has been an ambiguity between the educational function that leads to commerciality, especially in religious broadcast programs. Critical discourses related to the commercialization of television broadcast programs in the last five years do not 
seem to be discussed much because they are dominated by new media discourses as information media today. Meanwhile, several survey results still prove the strategic position of television as a medium of information and education for the Indonesian people. Looking upon previous research, this study was conducted to analyze the ambiguity that exists in religious broadcast programs on national television in 2021 . This study aims to analyze the position and function of religious broadcasting programs between education and commercialization. This research is expected to become a new discourse on the reality of Indonesian television broadcast programs.

\section{Method}

This research is a descriptive study as the basis of the research approach. Primary data from the research was obtained through a mix-method, a research method that combines qualitative and quantitative research to obtain comprehensive, valid, reliable, and objective data.(Creswell \& Creswell, 2018; Weibin Lin; Bin Chen; Shichao Luo; and Li Liang, 2013). The primary data of this study were obtained through observation and questionnaire methods. Non-participatory observations were carried out by viewing and analyzing religious broadcast programs on television from several Indonesian TV broadcasting stations by researchers and informants. Data collection using a questionnaire was used to complete the qualitative data obtained. The religious broadcast program studied was selected through 12 television stations in Indonesia, which is described in Table 1.

Table. 1 Television Stations and Religious Broadcasting Programs

\begin{tabular}{llll}
\hline No. & $\begin{array}{l}\text { Television } \\
\text { station }\end{array}$ & Religious Broadcasting Program & $\begin{array}{l}\text { (Literal Translation in } \\
\text { English) }\end{array}$ \\
\hline 1 & SCTV & Indahnya Kebersamaan & The beauty of togetherness \\
\hline 2 & RCTI & $\begin{array}{l}\text { Kultum, Rohani Kristen, Jalan } \\
\text { Tengah }\end{array}$ & $\begin{array}{l}\text { Preaching, Christian } \\
\text { Spiritual, Middle Way }\end{array}$ \\
\hline 3 & TV ONE & $\begin{array}{l}\text { Rumah Mama Dedeh, } \\
\text { Assalamu'alaikum Nusantara }\end{array}$ & $\begin{array}{l}\text { Mama Dedeh's house, } \\
\text { Assalamu'alaikum Nusantara }\end{array}$ \\
\hline 4 & TRANS 7 & $\begin{array}{l}\text { Khazanah, Para Nabi, Islam } \\
\text { Pedia, Hikmah }\end{array}$ & $\begin{array}{l}\text { Treasures, Prophets, Islam } \\
\text { Pedia, Wisdom }\end{array}$ \\
\hline 5 & INDOSIAR & $\begin{array}{l}\text { Tasbih, mu'jizat, Embun } \\
\text { Kehidupan }\end{array}$ & Tasbih, miracle, Dew of Life \\
\hline 6 & TVRI & $\begin{array}{l}\text { Jejak Islam Satukan Shaf, } \\
\text { Mimbar Agama Budha, Mimbar } \\
\text { Agama Konghuchu }\end{array}$ & $\begin{array}{l}\text { Traces of Islam Unite the } \\
\text { Shaf, Pulpit of Buddhism, } \\
\text { Pulpit of Confucian Religion }\end{array}$ \\
\hline 7 & COMPASS TV & Kalam Hati, Jejak Rasul & $\begin{array}{l}\text { Words of the Heart, Traces } \\
\text { of the Apostles }\end{array}$ \\
\hline 8 & RTV & Cermin Hati, Cahaya Ilahi & $\begin{array}{l}\text { Mirror of the Heart, Divine } \\
\text { Light }\end{array}$ \\
\hline 9 & METRO TV & $\begin{array}{l}\text { Sirah Nabawiyah, Dakwah on } \\
\text { The Spot }\end{array}$ & $\begin{array}{l}\text { Sirah Nabawiyah, Da'wah } \\
\text { on The Spot }\end{array}$ \\
\hline 10 & INEWS & $\begin{array}{l}\text { Cahaya Hati Indonesia, Worship } \\
\text { at Home }\end{array}$ & $\begin{array}{l}\text { Cahaya Hati Indonesia, } \\
\text { Worship at Home }\end{array}$ \\
\hline 11 & TRANS TV & Islam Itu Indah & Islam is beautiful \\
\hline 12 & MNC TV & $\begin{array}{l}\text { Siraman Qolbu, Bimbingan } \\
\text { Rohani }\end{array}$ & $\begin{array}{l}\text { Siraman Qolbu, Spiritual } \\
\text { Guidance }\end{array}$ \\
\hline & & &
\end{tabular}


The religious broadcast program analyzed was taken from the period JanuaryMarch 2021. The data analysis (Engle, 2015) is described in the following figure.

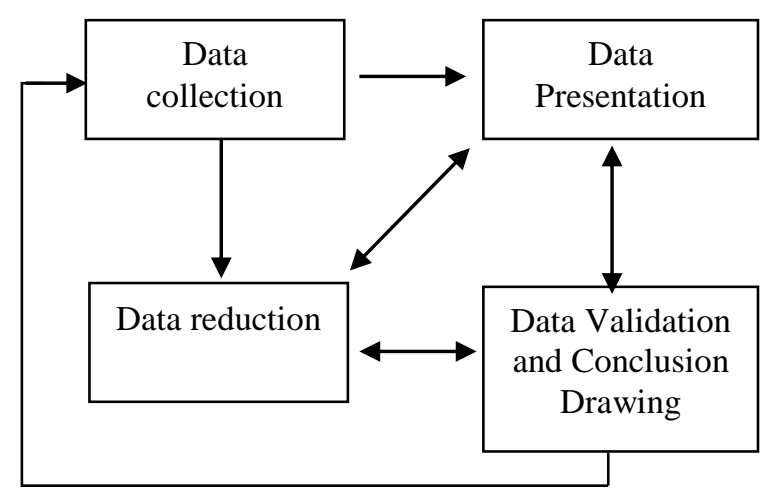

Figure 1. Data Analysis

Informants were selected by the researchers using a purposive technique (Creswell \& Creswell, 2018), where the researchers intentionally select competent and expert informants in a particular field of study. In analyzing the content of religious broadcast programs, informants were given a questionnaire to assess nine categories of religious broadcast programs from the broadcast samples given and asked to rate nine categories of religious broadcasting programs from a sample of broadcast programs. A scale rating using a Likert scale of 1 to 5 is given to facilitate informants in assessing the quality of religious broadcast programs based on the category of assessment given. To sharpen the results of the assessment, the informants were then given an open questionnaire to provide comments, analysis, opinions, and criticisms related to the religious broadcast program that was observed and analyzed. From the assessment that has been obtained, informants are then presented in FGD (Focus Group Discussion) to discuss the categories that have been analyzed. Secondary data collected through library references and previous research are also used in this study to support the wealth of research data.

\section{Results and Discussion}

Television in Indonesia is still a popular medium for the public to obtain information. According to Nielsen's research, in 2020, the average Indonesian spent around 5 hours watching television (Tupani, 2020). This shows that television in Indonesia still exists. In addition, considering that Indonesia is an archipelagic country and not all regions have access to the internet, television is one of the media that people from urban widely use to rural areas. Until now, television media still has a significant role in information and education. It is estimated that there are 1,027 television stations in Indonesia, including national, local, and regional television. Of this large number, only a few television stations have broadcast rights national such as TVRI, MNC Group (RCTI, Global, and MNC), SCTV-Indosiar Group, Trans-TV Group, and Viva Group (AnTV and TVOne)(Indonesian Information Portal, 2020). Various television broadcast programs are also served by television stations, a religious broadcast program.

The religious broadcast program is one of the themes of the broadcast program group monitored by the Indonesian Broadcasting Commission (KPI). Five dimensions are indicators of evaluating the content of religious broadcast programs to assess the 
quality of broadcast programs. The first dimension is respect for ethnicity, race, and religion. Second dimension is maintaining ethics, interreligious relations, and tolerance. The third dimension is the absence of horror, mystical, and supernatural content in religious content. The fourth dimension is the absence of sexual content. The fifth dimension is to build the character and identity of the nation. The assessment on the five dimensions of the broadcast program aims to maintain the quality of broadcast programs to fulfill the function of television as a medium of information, education, and social control.

Religious broadcast programs are broadcast programs that have religious-based content. Basically, a religious broadcast program is a broadcast program that presents religious content and becomes a forum for information for religious people in Indonesia. Indonesia is a diverse country with diverse customs and religious cultures. Based on Indonesia.go, there are six religions officially recognized by Indonesia, namely Islam, Protestantism, Catholicism, Hinduism, Buddhism, and Confucianism. Television as a mass media basically consists of three main aspects, namely audiences (audience), content (content), and media makers (institutions) (Baruah \& Hazarika, 2020; Sorlin, 2013). In relation to information, television has the characteristics of message-oriented, and messages that are general. In this context, ideally, television can present and provide balanced religious content information on religious broadcast programs. Balanced in this case is that each religion has a slot or program of viewing.

Based on the results of research and analysis conducted, in terms of the diversity of religious messages from religions in Indonesia, most television stations have not shown programs from all religions in Indonesia. Likewise, when viewed from the side of the frequency of broadcasts, it is still found that certain religions dominate when compared to other religions. Almost all religious program shows are still stuck with the power of the program name and the message conveying figure in each show. Religious broadcast programs broadcast through 12 television stations are still unable to present balanced broadcast content on various religions. This balance can be seen through 2 things: first is the number of programs on certain religious programs, and second is the religious content on broadcast programs, which can be seen in Figure 2 and 3.

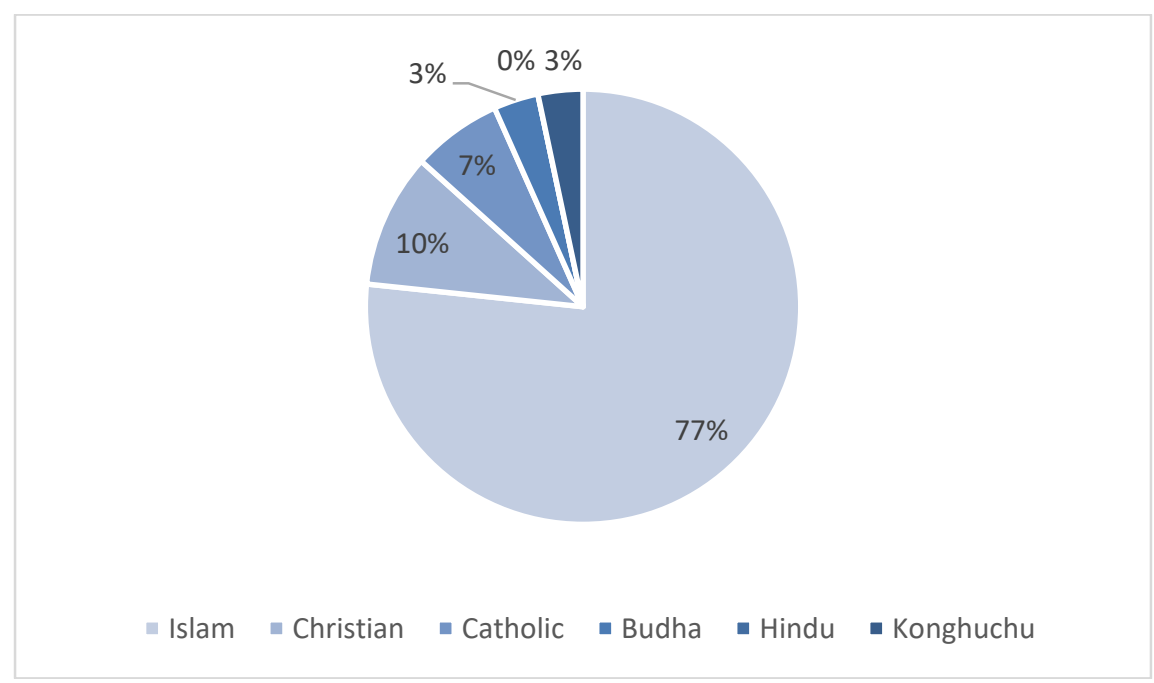

Figure 2. Number of Religious Broadcasting Programs 
Figure 2 shows the number of broadcast programs of certain religions on 12 television stations. There are 30 religious broadcast programs observed and analyzed by researchers. The Islamic religious broadcast program became the most religious broadcast program broadcast by television stations with a total of 23 broadcast programs. Christian religious broadcasting programs are in second place with three broadcasts followed by Catholic religious broadcasting programs 2, Confucianism 1, and Hindu 0 . The number of religious broadcast programs shows that Islamic religious broadcasting programs dominate with $77 \%$ of broadcast slots. This shows that the number of religious broadcast programs is still too dominated by one particular religious broadcast program and does not provide space for other religious broadcast programs. This balance can also be seen through the content of religious broadcasts on broadcast programs presented on Figure 3.

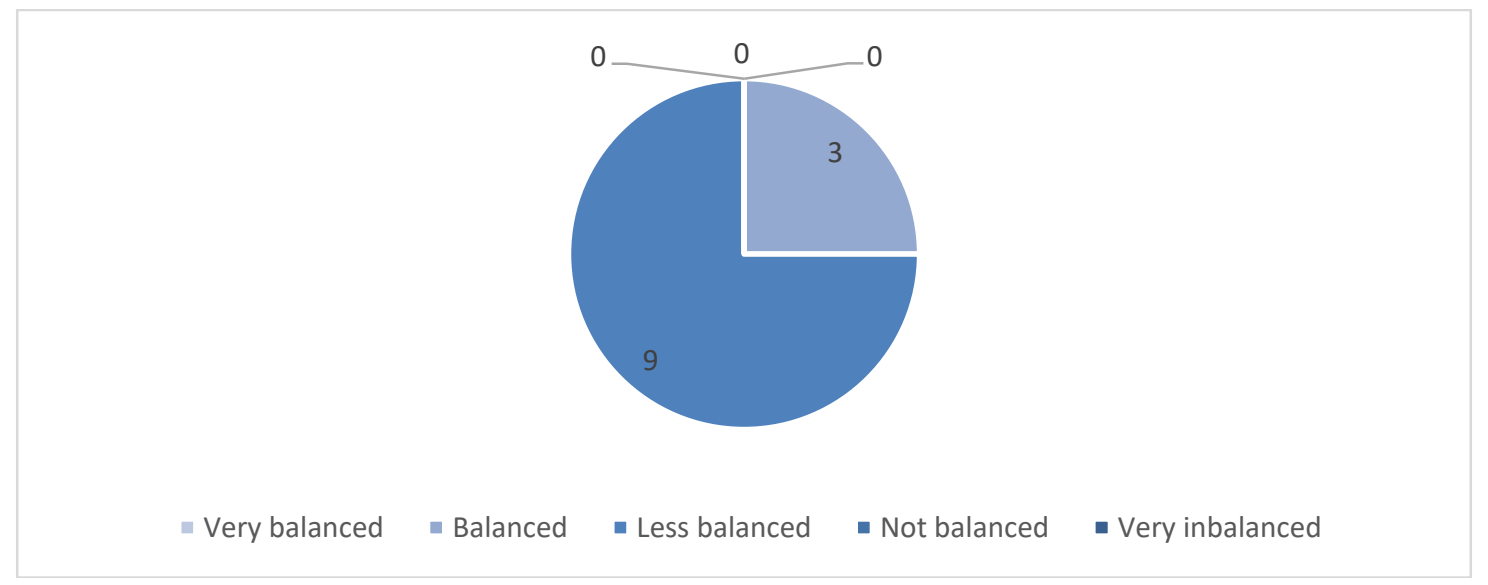

Figure 3. Balance of Religious Broadcast Content

One indicator of the balance of religious broadcast content assessment is that the religious broadcast program provides equal opportunities for various religions. Figure 3 shows the balance of religious broadcast content at each broadcast station. Based on the analysis of Figure 3, three television broadcast programs provide balanced religious content. In addition, nine of them are dominated by Islamic religious broadcast content, and one television station is dominated by Catholic religious broadcast programs. One television station which is dominated by Catholic religious broadcasting programs is RTV. This religious broadcast program has not given equal opportunities to existing religions because the program only contains six shows of the Catholic religion and only one program of Islam. Meanwhile, there is no material from other religions.

Three television stations are sufficient to provide equal opportunities for various religions in their broadcast content. The first is RCTI. Its broadcast shows existing religions, although it has not given opportunities to all religions, only on January 17, Christian Spirituality, and February 16, 2021, the Middle Way. On the Indosiar TV station, this religious program has provided broadcast space for religions other than Islam. For example, Miracles still Exists in the March 17 broadcast and the broadcast on February 14, 2021, Dew of Life. However, not all religious broadcast programs are broadcast on this program. The religious broadcast program on TVRI station is sufficient to provide space for three religions, namely Islam and Buddhism on March 4, 2021, and Confucianism on March 5, 2021. 
Meanwhile, nine other television stations tend to broadcast more Islamic religious content. Religious broadcast programs broadcast by TV ONE station, namely Rumah Mama Dedeh and Assalamu'alaikum Nusantara, are Islamic religious broadcast programs, and no other religious broadcast programs were found. At the TRANS7 station, the material in this religious show only contains material about the religion of Islam. It does not feature other religions, which consist of Khazanah, the Prophets, Islam Pedia, and Hikmah (Wisdom). On TRANSTV, the Islamic religious program Islam itu Indah (Islam is Beautiful) only conveys Islamic religious material, and other religions are not given a portion of the show. The same thing also happened to other television broadcast religious programs.

Islamic religious broadcast programs mostly embed Islamic identity in the name, setting, and character who conveys the message. The Islamic identity in this religious broadcast program narrows the broadcast content and tends to give exclusivity that the program only specifically broadcasts Islamic content. This identity is what narrows the broadcast content space so that it is not possible or difficult to allow religious broadcast programs with Islamic identities to broadcast other religious content. This condition is actually motivated by the dominant Muslim population in Indonesia. The Pew report said that the world's Muslim population is at 23\%, while Indonesia is the largest Muslim population with $13 \%$ of the world's total Muslim population, which will continue to increase. This is a huge number considering that the Indonesian market is dominated by Muslims (Grim \& Karim, 2011). Temporal said that Muslims tend to consume products in accordance with Shariah, namely in accordance with existing Islamic laws (Bukhari \& Isa, 2019; Hasan, 2019; Pink, 2020; Temporal, 2015).

"Shariah deals with legal aspects of day-to-day life, including politics, economics, banking, business, contracts, family law, sexuality, and social issues ..... The practice of Islam under Shariah law has for centuries been the basis of Islamic trade and business, and there are well-established rules and standards in place to ensure that the law is observed by practicing Muslims." (Temporal, 2015)

For example, in food products, the halal label is one of the critical things for Muslims. In the economic field, transactions based on sharia have a higher positioning than transactions in general. Seeing this condition, Muslims today become a large market and allow Islamic content to be more in demand in Indonesia. The media has enabled the creation of the most fragmented market into a lucrative opportunity, especially for the Muslim consumer market. The Muslim market is still and will continue to grow, and this can be an opportunity for producers to take advantage of opportunities in targeting the market. Religious broadcast programs on television stations in Indonesia dominated by Islamic topics indicate a tendency for commercialization of these programs. Of course, religious broadcast programs with Islamic themes will be watched by more Indonesians who are Muslim, which is $87.2 \%$ of the total population of Indonesia.

This religious broadcast program, which is mostly filled with Islamic content, is also dominated by programs and messenger figures who are well-known for their names and programs. Three television stations use the names of the messengers and programs, namely MNC TV, TV ONE, SCTV, and TRANS TV. These religious broadcast programs include Siraman Qolbu, Kata Ustad Solmed, Mama Dedeh's House, Islam is Beautiful. The selection of figures as resource persons in religious broadcast programs represents more figures with selling points and are attractive to viewers. The figure of Mama Dedeh has not changed for years with the name of the same broadcast program, 
namely since 2006. The figure of Ustadz Danu, who has a big name, is still a messenger in religious broadcast programs despite being stumbled by controversy. The figure of Ustadz Maulana with his broadcast programs that often feature celebrities, and with the same television broadcast program since 2009. Of the four religious broadcast programs, the name of the messenger figure and or the name of the program becomes a selling point as evidenced by the figure of the messenger that does not change until years and the name of the program that has not changed nor has an identity related to the program.

In addition to the imbalance in the content of religious broadcast programs, which tend to contain more Islamic material, and the dominance of program names and presenters, it was also found through the FGD that there are still some religious broadcast programs that are less educational or in accordance with the context of information and religious education that should be given. Based on the television broadcast quality index research conducted by the Indonesian Broadcasting Commission, one indicator of a quality religious broadcast program is that it is free from mystical, horror, and supernatural elements. This element has a tendency that is less educative and is not in accordance with the purpose of religious broadcasts, namely information and education about religion.

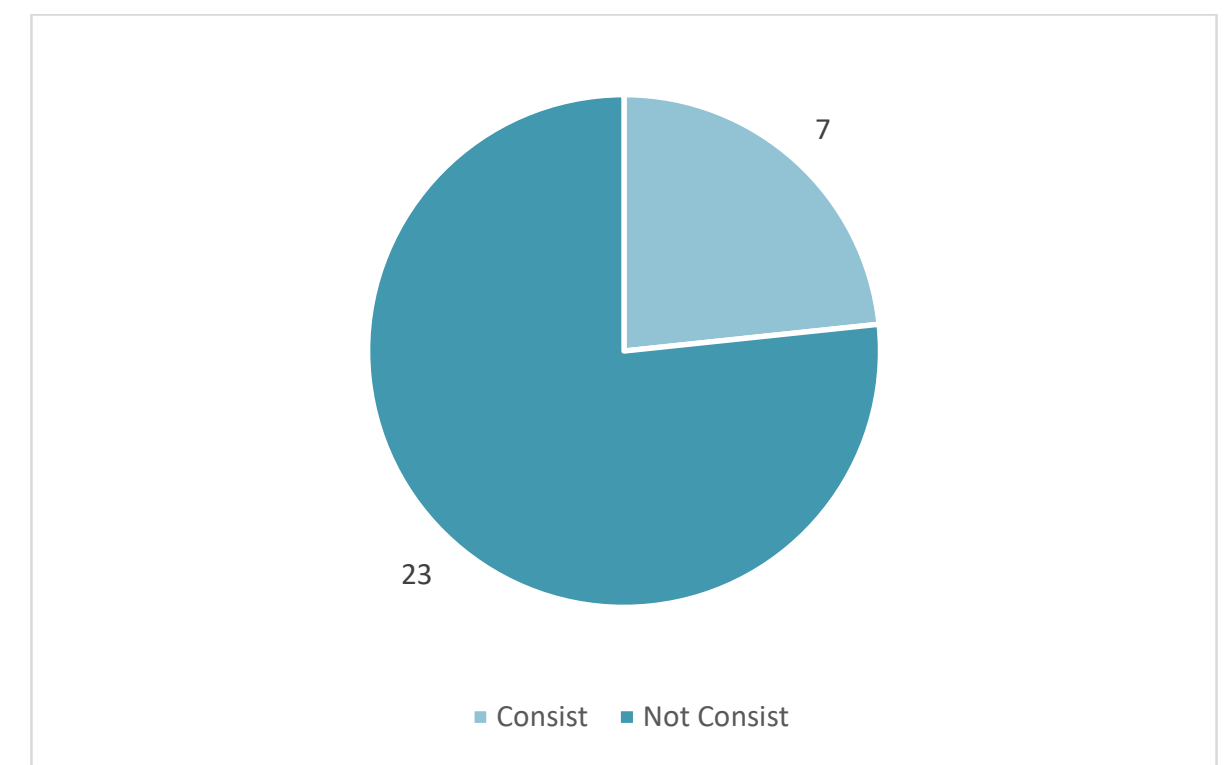

Figure 4. The Charge of Mystical, Horror, and Supernatural Elements

Figure 4 shows that some religious broadcast programs contain mystical, horror, and supernatural elements. Seven broadcast programs have mystical, horror, and supernatural content on religious broadcasts. Although the number of broadcast programs that still have mystical, horror, and supernatural content is not much, this notes that the mystical, horror, and supernatural elements are not in line with the content of religious broadcasts aimed at preaching and educating certain religions.

Some materials contain mystical, horror, and supernatural content on the broadcast station TRANS 7, namely on Khazanah's broadcast on February 4, 2021, about a snake that comes in the house associated with the jinn and Nyi Blorong. Mystical, horror, and supernatural content was also found in the Islam Pedia broadcast material on March 5, 2021. The content indicated that menstruating people were not allowed to enter chili 
plantations because there was a belief that chilies would rot and fall out. Furthermore, the Hikmah program, on February 14, 2021, presented its material broadcast about jinn and demons by featuring Roy Kiyosi. Apart from having mystical, horror, and supernatural content, this show lacks the content of forming and building the nation's character because there are shows related to mystical beliefs and the world of jinn and demons. This is not relevant to the formation of people's character.

The religious program broadcast at INDOSIAR, which still contains supernatural horror and the supernatural, is shown in the Miracle Show on March 17, 2021, which says God's word came. God's power came when he was sick with Covid. In addition, the religious broadcast program on the KOMPAS TV station also conveyed a message of horror on the Trace of the Rosul broadcast on February 14, 2021, which featured the terrible corpse of Pharaoh at 03.33 minutes. Religious shows on RTV show that not all are free from mystique, horror, and the supernatural. The broadcast of religious programs on January 9, 2021, and February 14, 2021, still found mystical, horror, and supernatural elements even though they were in the form of illustrations. MNC TV on religious programs still broadcast mystical and horror elements, as shown through unnaturally sick audience who then asked Ustadz Danu to pray. Another broadcast on February 14, 2021 also recounted a strange incident through the impression of a person on a plane that wanted to crash but did not happen.

Several religious broadcast programs show that there are still mystical, horror, and supernatural shows that are not in accordance with the content of religious broadcast programs, a note that the educational function of religious broadcast programs is still not appropriate. On the one hand, these mystical, horrors, and supernatural shows negatively impact the audience (Hikmat, 2019). On the other hand, mystical, horror, and supernatural content are still very popular in public. As shown by the results of a survey conducted by KOMINFO, mystical content is one of the shows with a high rating.

Seeing this fact, religious broadcasting programs still prioritize commercialization by pursuing the number of audiences rather than information or education. Although mystical, horror, and supernatural content do not dominate television broadcast programs, they can distract the audience or even give a wrong understanding of the religious information provided. According to Rachmiatie (Hikmat, 2019), mystical, horror, and supernatural broadcasts are harmful to the deterioration of cognition, attitudes, and behavior; can lead to justification for irrational living conditions, tolerance for evil, envy, jealousy, suspicion, and other heart diseases; can lead to unproductive and permissive behavior towards a cutting-edge mental attitude; can create fear, anxiety, stress, and other negative emotions.

Mass media has the power to evoke emotions from the audience, like the news of a hawker packaged sadly to touch the heart, or the celebration of the victory of a football team that is packaged spectacularly so that the audience can feel the euphoria of victory (Döveling et al., 2010; Galetić \& Dabić, 2020; Gever et al., 2021). The packaging of religious broadcast programs that carry mystical, horror, and supernatural content can provide a message bias or different interpretation for each audience. Therefore, the mass media has the characteristics of general messages. In this case, mass media should minimize the bias of messages received by the audience as much as possible. Mystical, horror, and supernatural shows are still being debated, and not all Indonesian people can accept this kind of content well, according to the diverse and heterogeneous character of the Indonesian audience. 


\section{Conclusion}

Television as a mass media in Indonesia based on Law no. 32 of 2002 Article 4 Paragraph 1 functions as a medium of information, education, healthy entertainment, control, and social congeal. In the religious broadcast program, two functions need to be considered, namely the function of education and information. 89\% of Indonesians still trust information broadcast on television more than the internet. Actually, this is an opportunity for the mass media to implement the function of information and education in the context of building Indonesian society. This research found that there are imbalanced religious contents where religious broadcast programs are dominated by Islamic religious content. In addition, it was found that there were mystical, horror, and supernatural contents in several religious broadcast programs, which were not educational. The last finding in this study was the trapping of religious broadcast programs in the names of the messenger figures and the program names. The results of this study are a strong indication of television, still prioritizing the commercialization of broadcast programs and the shifting of the educational function.

\section{Acknowledgment}

This research is the result of the Indonesian Broadcasting Commission's (KPI) Television Program Quality Index Research in collaboration with UIN Sunan Kalijaga Yogyakarta. The author expresses his deepest gratitude to the Indonesian Broadcasting Commission (KPI) and the 2021 Indonesian Broadcasting Conference Committee Hassanudin Makassar University, who have participated in helping the completion of this paper.

\section{References}

Abdullah, A., \& Puspitasari, L. (2018). Media Televisi Di Era Internet. ProTVF, 2(1), 101. https://doi.org/10.24198/ptvf.v2i1.19880

Alansori, M. Z., \& Zahidi, S. (2019). Dakwahtaiment Televisi Lokal (Tinjauan Kritis Atas Komesialisasi Dakwah JTV Surabaya). Journal of Islamic Civilization, 1(2), 70-82. https://doi.org/10.33086/jic.v1i2.1341

Alfian, M. I. (2014). Dakwahtainment: Antara Komersialisasi Media Di Balik Ayat Tuhan. At-Tabsyir, 2(1), 133-148.

Andung, P. A., Sjuchro, D. W., Liliweri, A., \& Hadisiwi, P. (2018). Posisi Media Televisi dalam Membangun Nilai-Nilai pada Masyarakat Perbatasan. Jurnal ASPIKOM, 3(5), 917. https://doi.org/10.24329/aspikom.v3i5.289

Aprinta, G. (2016). Jurnalisme Reportase: Sebuah Produk Komersialisasi Dalam Industri Televisi. Jurnal The Messenger, 4(1), 27. https://doi.org/10.26623/themessenger.v4i1.274

Baruah, D. T. D., \& Hazarika, D. J. (2020). Use of Mass Media Tools for Effective Social and Behaviour Change Communication. Krishna Kanta Handiqui State, 23.

Bukhari, S. N. Z., \& Isa, S. M. (2019). Islamic branding: insights from a conceptual perspective. Journal of Islamic Marketing. https://www.emerald.com/insight/content/doi/10.1108/JIMA-02-20180035/full/html

Creswell, J., \& Creswell, J. (2018). Research design: Qualitative, quantitative, and mixed methods approaches. Sage publications.

Döveling, K., von Scheve, C., \& Konijn, E. A. (2010). The Routledge handbook of emotions and mass media. In The Routledge Handbook of Emotions and Mass 
Media. Routledge. https://doi.org/10.4324/9780203885390

Engle, M. (2015). Book Review: Qualitative Data Analysis: A Methods Sourcebook: The Coding Manual for Qualitative Researchers. In American Journal of Evaluation (Vol. 36, Issue 1). https://doi.org/10.1177/1098214014556146

Galetić, F., \& Dabić, M. (2020). Models of television market power in Germany and Croatia. Technology in Society, 63. https://doi.org/10.1016/j.techsoc.2020.101359

Gever, V. C., Tunca, E. A., Boluwatife, A. A., Nwogbo, V. C., Chinweobo-Onuoha, B. N., Ugwuoke, J. C., \& Talabi, F. O. (2021). Visual media and learning: Effect of interactive television instruction as an intervention strategy for improving the critical thinking skills and disposition of out-of-school nomadic children in Nigeria. Learning and Motivation, 76. https://doi.org/10.1016/j.lmot.2021.101767

Grim, B. J., \& Karim, M. S. (2011). The Future of the Global Muslim Population - Pew Forum on Religion ... The Future of the Global Muslim Population - Pew Forum on Religion … https://assets.pewresearch.org/wpcontent/uploads/sites/11/2011/01/FutureGlobalMuslimPopulation-WebPDFFeb10.pdf

Haqqu, R., \& Azwar Ersyad, F. (2020). Eksistensi Media Televisi Era Digital Dikalangan Remaja. Jurnal Dinamika Sosial Budaya, 22(1), 38. https://doi.org/10.26623/jdsb.v22i1.2228

Hasan, M. (2019). Social marketing: an Islamic perspective. Journal of Islamic Marketing. https://www.emerald.com/insight/content/doi/10.1108/JIMA-12-20160105/full/html

Hendra, T. (2019). Media Massa Dalam Komunikasi Pembangunan. Jurnal At-Taghyir: Jurnal Dakwah Dan Pengembangan Masyarakat Desa, 1(2), 136-152. https://doi.org/10.24952/taghyir.v1i2.1723

Hikmat, M. M. (2019). Tahun Mistik, Horor, dan Supranatural”. Komisi Penyiaran Indonesia. Komisi Penyiaran Indonesia. http://www.kpi.go.id/index.php/id/umum/38-dalam-negeri/34900-tahun-mistikhoror-dan-supranatural

Irfan, K. (2020). KPI: 89 Persen Masyarakat Lebih Percaya Televisi Dibanding Internet. Kompas.Com. https://nasional.kompas.com/read/2020/07/22/20263851/kpi-89-persenmasyarakat-lebih-percaya-televisi-dibanding-internet

Kementrian Komunikasi dan Informasi. (2020). Status Literasi Digital Nasional. In Katadata Insight Center. https://katadata.co.id/statusliterasidigital

Liu, Q., Zheng, Z., Zheng, J., Chen, Q., Liu, G., Chen, S., Chu, B., Zhu, H., Akinwunmi, Ba., Huang, J., Zhang, C. J. P., \& Ming, W. K. (2020). Health communication through news media during the early stage of the covid-19 outbreak in China: Digital topic modeling approach. Journal of Medical Internet Research, 22(4). https://doi.org/10.2196/19118

Nicolaou, C. (2021). Media trends and prospects in educational activities and techniques for online learning and teaching through television content: Technological and digital socio-cultural environment, generations, and audio-visual media communications in education. Education Sciences, 11(11). https://doi.org/10.3390/educsci11110685

Pink, J. (2020). Muslim societies in the age of mass consumption: Politics, culture and identity between the local and the global. books.google.com. https://books.google.com/books?hl=en\&lr=\&id=oLzxDwAAQBAJ\&oi=fnd\&pg= 
PR5\&dq $=$ islamic + branding\&ots $=$ Xmcfn42 $x o H \&$ sig $=$ suF0smIdhYwB63t1a6TM5 $\mathrm{Xr} 71 \mathrm{x} 8$

Portal Informasi Indonesia. (2020). Percepatan Langkah Menuju TV Digital. Indonesia.Go.Id. https://indonesia.go.id/kategori/indonesia-dalamangka/1937/percepatan-langkah-menuju-tv-digital

Pradesa, D., \& Ardilla, Y. P. (2020). Komodifikasi dan efek eksternalitas program dakwahtainment islam itu indah. INTELEKSIA-Jurnal Pengembangan Ilmu Dakwah, $02(01)$, 81-106. http://inteleksia.stidalhadid.ac.id/index.php/inteleksia/article/view/85

RG. (2020). Literasi Harus Menyasar Masyarakat Pengguna Internet. Komisi Penyiaran Indonesia. http://www.kpi.go.id/index.php/id/umum/38-dalamnegeri/35832-literasi-harus-menyasar-masyarakat-penggunainternet?detail3 $=9825$

Romli, K. (2017). Komunikasi Massa. Grasindo.

Santosa, B. A. (2017). Peran Media Massa dalam Mencegah Konflik. Jurnal ASPIKOM, 3(2), 199-214. http://jurnalaspikom.org/index.php/aspikom/article/view/128/104

Servaes, J. (2020). Communication for development and social change: Conclusion. In Handbook of Communication for Development and Social Change (Issue February). https://doi.org/10.1007/978-981-15-2014-3_116

Shah, H. (2011). The production of modernization: Daniel Lerner, Mass Media, and the passing of traditional society. Temple University Press, 1(1), 1-218. https://doi.org/10.1177/0094306112468721aa

Sorlin, P. (2013). Mass Media. In Routledge. Routledge. https://doi.org/10.5840/renascence19579428

Susanto, E. H. (2017). Media Massa, Pemerintah dan Pemilik Modal. Jurnal ASPIKOM, 1(6), 477. https://doi.org/10.24329/aspikom.v1i6.53

Temporal, P. (2015). Islamic Branding and Marketing: Creating a Global Islamic Business. In Journal of Islamic Marketing. John Wiley \& Sons. https://www.google.co.id/books/edition/_/-

8GDswEACAAJ?hl=en\&sa=X\&ved=2ahUKEwjpgfnMtqb1 AhVL63MBHavRAe gQ8fIDegQIBhAH

Thadi, R. (2020). Analisis Kritis Sinetron Religi: Antara Dak-wah dan Kepentingan Komersil. DAWUH: Islamic Communication Journal, 1(1), 9-16.

Tupani, D. (2020). Nielsen: Covid-19 Tingkatkan Jumlah Penonton Televisi. In Media Indonesia.com. https://mediaindonesia.com/humaniora/298392/nielsen-covid-19tingkatkan-jumlah-penonton-televisi

Ulfah, M. (2014). Kontestasi Komodifikasi Media Massa dan Ideologi Muhammadiyah. Jurnal ASPIKOM, 2(3), 165. https://doi.org/10.24329/aspikom.v2i3.68

Weibin Lin; Bin Chen; Shichao Luo;and Li Liang. (2013). Qualitative, quantitative, and mixed methods approaches. In Research design (Fifth Edit). Sage Pubs. http://www.thestar.com.my/news/nation/2016/03/21/schools-in-kedah-and-perlisto-close-on-tuesday-and-wednesday-due-to-heatwave/

Wibowo, A. (2020). Komodifikasi Agama: Studi Analisis terhadap Tampilan Agama di Media Televisi. Edugama: Jurnal Kependidikan Dan Sosial Keagamaan, 6(1), 56-74. https://doi.org/10.32923/edugama.v6i1.1325

Wilkins, K.G., Tufte, T. and Obregon, R. (2014). The Handbook of Development Communication and Social Change. In The Handbook of Development Communication and Social Change. John Wiley \& Sons. 
https://doi.org/10.1002/9781118505328

$\mathrm{Xu}, \mathrm{M}$. (2015). Commercial reform and the political function of Chinese television. Telematics and Informatics, 32(2), 367-377. https://doi.org/10.1016/j.tele.2013.09.002 